compounds, iron and manganese, derived from the land, exert a strongly favourable influence on phytoplankton production.

The importance of the pack-ice in maintaining the flora within the Antarctic zone is much emphasized. It is even more marked than earlier observations suggested. By means of the pack-ice neritic species are maintained very far from land and flourish for short periods when the ice disperses.

It is here confirmed, as is already noted by former observers (Marshall, Gross and others), that Calanoids are capable of triturating and swallowing the larger spiny diatoms as well as ingesting the smaller species entire. The author's examination of stomach contents showed that in addition to Euphausia superba, other Euphausiids, some of the most important Calanoids and some of the more abundant Pteropods, all feed extensively on diatoms.

\section{INTERNATIONAL LAW AND MORALS}

$\mathrm{P}_{\mathrm{r}}^{\mathrm{H}}$ ROF. MORRIS GINSBERG wisely chose for his presidential address to the Aristotelian Society* a theme relevant both to his own distinguished work as a sociologist and to the world crisis which perforce dominates public attention at the present time. $\mathrm{He}$ sets himself to show how the trend towards an individualist doctrine in ethics is discernible also in recent developments of international law, attended there by "a certain lag in applying the criticisms which in the course of the nineteenth century were directed against the principles of individualism" (for example, the right of property and freedom of contract) in the internal economy of States, to the problem of the relations between States, a lag that is in no small measure responsible for our present international troubles and calls urgently for rectification. The only remedy, he contends (and the contention is supported by much judicious illustration), lies in the establishment of an effective supra-national authority. It makes little difference to this conclusion whether a utilitarian eriterion or a doctrine of natural rights be adopted as the basis of the theory of international law ; for the advocates of both these positions have carried the individualist interpretation to an extreme that precludes any satisfactory solution of international problems. Prof. Ginsberg's discussion of the concepts of equality, freedom and self-determination and of the difficulties provoked by each when held to be natural rights is perhaps the most masterly section of his address.

Three points in his review call for special notice. Not only is he convinced that the problem of international relations is a moral one; but it is so regarded by public opinion, both at home and, as has erroneously been questioned, in enemy countries. Nazi propaganda has won its way in Germany by an appeal to justice and denunciation of the alleged injustice of which Germany has been the victim. The theorists of the movement "even go to the length of claiming that they have bridged the gulf between law and morals and that their law alone is richtiges Recht". It is vitally important for us all to realize that the conflict in which we are engaged is being fought out

*"The Individualist Basis of International Law and Morals", by Morris Ginsberg, being the Presidential Address to the Aristotelian Society, 194:-3. on ethical terrain by both sides. It is a conflict of one set of moral principles against another.

Secondly, on both sides, the ethical concept of justice is in the forefront. Prof. Ginsberg follows Sidgwick in holding that the principle of seeking happiness needs supplementing by that of just distribution. So, again, there can be no peace among the nations without justice, and justice implies positive co-operation for common ends. Lastly, he has some interesting remarks towards the close on the error, into which many thinkers on politics have fallen, of presenting the issue now before the world as whether the individual exists for the State or the State for the individual. To posit the antithesis thus is to over-simplify the real problem. "There is clearly a need," he says, "for a great variety of corporate bodies to mediate between the mass of individuals and the community of mankind." This need is increasingly urgent in the larger among modern States, and is winning recognition in federal communities like the British Commonwealth, the American Union and the U.S.S.R. A great deal of the work of self-government is carried on, not within the bounds of constitutional machinery (where the individual citizen scarcely counts, even when he is voting), but through participation in non-official groups, churches, universities and learned societies, professional organizations and trade unions.

We are duly grateful to Prof. Ginsberg for directing attention to the part such groups may play in the solution of international problems.

\section{W. G. DE BURGH.}

\section{CIVILIAN CONTRIBUTION TO EDUCATION IN H.M. FORCES}

$\mathrm{T}$

HE report of the Central Advisory Council for Adult Education in H.M. Forces for the period April-September 1942 reflects great credit on all the civilian authorities who constitute the Central Advisory Council. The launching of the educational scheme in the Forces could scarcely have been possible without the active participation of the Central Advisory Council, while any success it may have achieved is due in large measure to the substantial assistance provided by the regional committees of the Central Advisory Council in the various administrative areas. It is early yet to assess the real worth of this tremendous educational experiment, but already there is sufficient evidence to show that, by means of talks and discussions on various aspects of citizenship, those who have been responsible for the development of education in the Fighting Services have done much to develop a sense of civic awareness and responsibility among the people who are the potential citizens of Great Britain. Despite the difficulties of travelling in the black-out, the geographical isolation of Army and Air Force units, the cancellation of lectures at short notice owing to military exigencies and other factors which give rise to a considerable amount of exasperation and frustration, civilian lecturers have steadily continued to offer their services under the Scheme for Education in H.M. Forces. The statements in this report bear testimony to their achievements.

An analysis of the statistics brings out some interesting observations. During the period under review (April 1942-September 1942) the Central Advisory Council arranged some 44,695 single 